\title{
Issues of Lattice Structures Production via Metal Additive Manufacturing
}

Pavel Hanzl, Ivana Zetková, Milan Daňa

Faculty of Mechanical Engineering, University of West Bohemia. Univerzitní 2732/8, 30614 Pilsen. Czech Republic. Email: hanzlp@rti.zcu.cz, zetkova@rti.zcu.cz, danam@rti.zcu.cz

Metal additive manufacturing (MAM) is used in the production of parts, where a product is built layer by layer. MAM includes Direct Laser Metal Sintering (DMLS), which allows the production of complex metal parts directly from 3D software models without using sometimes expensive tools such as moulds, dies and cutting tools. New possibilities in the production of complicated components are made available using this advanced manufacturing technology. Nevertheless, this technology has limits, resulting from the method of melting in the powder bed. Therefore, this paper investigates the ability to produce fine cellular lattice structures. Some structures with selfsupporting cell units were selected for experimentation and were produced with identical cell size and volume fraction. Based on this, a suitable topology was established for the production of fine structures with small volume fractions.

Keywords: Lattice Structures, Rigid Constructions, Additive Manufacturing, Selective Laser Melting

\section{Acknowledgement}

This paper is based upon work sponsored by project SGS-2016-005 and "Regionální technologický institut" reg. no. CZ.1.05/2.1.00/03.0093.

\section{References}

[1] SHELLABEAR, M., NYRHILÄ, O. Advances in materials and properties of direct metal laser-sintered parts, Available from: http://www.rm-platform.com/index2.php?option=com_docman\&task=doc_view\&gid=549\&Itemid=1

[2] SEDLÁK, J., KUDLACOVÁ B., ZEMČÍK, O., JAROŠ, A., SLANÝ, M. (2017). Production of Planetary Mechanism Model Prototype using Additive Method of Rapid Prototyping, In Manufacturing Technology, vol. 17, No. 3, pp. 374-381.

[3] MAJERNÍK, J., KMEC, J., GOMBÁR, M., PODAĽIL, M. (2017). The Use of Simulation Programmes for the Structural Analysis and Engineering Optimization of Gasting System Structures for Use with High Pressure Die Casting Technology, In Manufacturing Technology, ISSN 1213-2489, vol. 17, No. 3, pp. 343-347.

[4] PAUL, R., AMAND, S. (2011). Optimal part orientation in Rapid Manufacturing process for achieving geometric tolerances, Published by Elsevier Ltd., Journal of Manufacturing Systems 3D (2011) 214-222

[5] HUSSEIN, A., HAO, L., YAN, C., EVERSON, R., YOUNG, P. (2013). Advanced lattice support structures for metal additive manufacturing, Published by Elsevier Ltd, Journal of Materials Processing Technology 213 (2013) 1019-1026

[6] AREMU, A. O. all et. A Comparative finite element study of cubic unit cells for selective laser melting, EPSRC Centre for Innovative Manufacturing in Additive Manufacturing, Faculty of Engineering, University of Nottingham, Nottingham, NG7 2RD, UK.

[7] CONTUZZI, N., CAMPANELLI, S. L., CASAVOLA, C., LAMBERTI, L. (2013). Manufacturing and Characterization of 18Ni Marage 300 Lattice Components by Selective Laser Melting, Materials 2013, 6, 3451-3468; doi:10.3390/ma6083451

[8] MONKOVA, K., MONKA, P. (2017). Some aspects influencing production of porous structures with complex shapes of cells, Published by Springer.

[9] KHADERI, S. N., DESHPANDE, V. S., FLECK, N. A. (2013). The stiffness and strength of the gyroid lattice, Departmant of Engineering, Cambridge University, Cambridge 